\title{
GENERATION Z IN BRICK-AND-MORTAR STORES: A REVIEW AND RESEARCH PROPOSITIONS
}

\author{
Katija Vojvodić ${ }^{23}$
}

UDC / UDK: 658.89:316.346.36-053.6; 004.738.5:339.37

JEL classification / JEL klasifikacija: J1, L81

DOI: https://doi.org/10.22598/pi-be/2019.13.1.105

Scientific review / Pregledni rad

Received / Primljeno: March 12, 2019 / 12. ožujka 2019.

Accepted for publishing / Prihvaćeno za tisak: April 30, 2019 / 30. travnja 2019.

\section{Summary}

Unlike the earlier generational cohorts of Baby Boomers, Generation X, and Generation $Y$, the Generation $Z$ (known as post-millennial generation) is still underresearched topic in the context of their retail-related behaviour. Although there are notable distinctions between the generations, it can be argued that each generational cohort affects the way traditional brick-and-mortar retailers do business. In addition, traditional retail is facing increasing competition, particularly from online retailers. Furthermore, shopping habits strongly reshape the retail industry, so brick-and-mortar retailers need to adapt their strategies to meet the requirements of today's rapidly changing consumers. Drawing on the previous literature, the purpose of this paper is to identify the main features of the post-millennial generation in brick-and-mortar retail settings. Furthermore, the paper develops a framework that can both guide future research and help traditional brick-and-mortar retailers to better target the postmillennial generation. As far as traditional retailers are concerned, the proper approach to Generation $Z$ cohort seems to be essential to capture this market segment more effectively and to improve their overall in-store shopping experience.

Key words: brick-and-mortar retailers, Generation Z, consumer behaviour

\section{INTRODUCTION}

It is generally accepted that experiences shape our behaviour and influence our personality. In that context, generational cohort theory posits that each generation is characterised by somewhat predictable traits directly attributable to events in their

${ }^{23}$ Katija Vojvodić, Ph.D., Associate Professor, University of Dubrovnik, Department of Economics and Business Economics, E-mail: katija.vojvodic@unidu.hr 
formative years (Benckendorff and Moscardo, 2013). Similarly, Parment (2012) notes that generational cohorts are distinguished by different events and experiences that produce a change in their values, attitudes and predispositions in a society. More specifically, Lantos (2011) emphasizes that a generation experiences a common social, political, historical, technological, and economic environment as well as a similar significant, defining, or formative life events. As a result, such an environment together with accompanying events affect their behaviour and create values that remain relatively unchanged throughout their lives (Schewe and Meredith, 2004).

Consequently, Glass (2007) states that members of all generations experience defining events between the ages of 5 to 18 , which affect their outlook on life and work. Moreover, Cohler and Hostetler (2003) stress that these events may change their outlook on life due to subsequent historical and social change that takes place across the adult life. Furthermore, Benckendorff et al. (2010) emphasize that this distinctive and unique pattern of values, attitudes and behaviours has important implications for how a generation will respond to, and create changes in, social and economic context. According to McCrindle (2014), many of generational labels can be applied globally because generational commonalities cross global boundaries.

Although there are notable distinctions between the generations, it can be argued that each generational cohort affects the way traditional brick-and-mortar retailers do business. Increasingly, Generation $\mathrm{Z}$ is emerging as a topic of interest in the recent academic and practitioner literature. As stressed by Moschis et al. (2000), age groups must be understood for their specific needs and situations as consumers, and this is particularly true for Generation Z. However, contrary to other generational cohorts, not much is known about Generation $\mathrm{Z}$ in the retail context. Therefore, it is crucial for retailers to develop a solid understanding of members of the Generation $Z$ and to communicate with them.

To advance understanding of Generation $\mathrm{Z}$ consumers in the retail environment, the paper presents the results of an extensive review of the recent literature on Generation $\mathrm{Z}$ members and their consumer-related behaviour. The purpose of this paper is to explore the concept of generational cohort referred to as Generation $\mathrm{Z}$ and its implications for the brick-and-mortar retail and to determine a framework for classification and analysis. Therefore, the paper is structured as follows. After the introduction, the second section gives a brief overview of retail-related behaviour of Baby Boomers, Generation X and Generation $Y$, all preceding Generation $Z$ what is defined in the third section. The fourth section examines Generation $\mathrm{Z}$ in the physical retail environment. The fifth section deals with the directions of future research on Generation Z, particularly in the context of smart innovative technologies. Finally, some conclusions are drawn in the final section.

\section{INSIGHTS INTO RETAIL BEHAVIOUR OF GENERATIONAL COHORTS}

There is no general agreement regarding the age boundaries referring to each generational cohort, thus various classifications can be found. In that context, Sagrestano 
and Wahlers (2012) identify the following generational cohorts: the Traditionalists (born pre-1946), the Baby Boomers, Generation X and the Millennials. As stated in the Introduction, generational cohorts affect traditional retailers who should be aware of the market potential of each generational segment in order to target them more effectively. This section observes the main retail-related features of the three generational cohorts that had preceded Generation Z, i.e., the Baby Boomers, Generation X and Generation Y.

\subsection{The Baby Boomers}

The Baby Boomers are commonly defined as the cohort of people born between 1946 and 1964 (Moschis et al., 2000; Worsley, Wang and Hunter 2011). Given that this cohort consists of ageing consumers, it is important to understand their specific needs in order to improve their overall shopping experience. In the context of retail buying behaviour, the purchase process for the Baby Boomers starts with a retailer that consumer trusts (Parment, 2013). Furthermore, for this cohort, the role of sales personnel and personal interaction is of the utmost importance in the retail settings (Meneely, Strugnell and Burns 2009). In addition, the Baby Boomers consider shopping to be a means of socialisation (Myers and Lumbers 2008) and a way to reduce their loneliness and to enhance social interaction (Pettigrew 2007).

In broad sense, this generational cohort is worried about their health and wellbeing (Worsley, Wang and Hunter, 2011). Compared with younger consumers, they spend more money on average at food stores (Moschis, Curasi and Bellenger 2004). According to Pak and Kambil (2006), psychological, social, economic and biological changes affect their spending habits and priorities. Consequently, they are facing a number of in-store difficulties and challenges, e.g. store size and changing layout (Meneely, Strugnell and Burns 2009), product packaging (Sudbury-Riley, 2014), the appropriate placement of products, shelf height and poor signage (Yin, Pei and Ranchhod, 2013).

\subsection{Generation $X$}

Following the Baby Boomers, Generation X comprises individuals born between the years 1965 and 1980 (Gibson, Regina and Edward, 2009; Ordun, 2015). Individuals that belong to the Generation X are also known as the postbaby-boomers, Baby Buster, Regeneration, the cable generation and the new lost generation (Leung and Taylor, 2002). Broadly speaking, Generation $X$ is described as hardworking, education-oriented, achieving, and family- and community-oriented (Miller and Laspra, 2017). They are also financially responsible and are likely to look for the lowest cost of item or for the discount (Ordun, 2015).

Compared with the previous generational cohort, Generation X is highly affected by technology. Moreover, they are very motivated to look for purchase-related information and are very skilled at searching (Ordun, 2015). According to Brosdahl and Carpenter (2012), Generation X consumers demonstrate a strong preference for Internetonly retailers. Similarly, Dhanapal, Vashu and Subramaniam (2015) affirm that both Generation X and Y do more online shopping than Baby Boomers. Likewise, Wyn (2012) 
emphasizes that adherent to Generation X are reluctant change makers. On the other hand, they are inclined to be impulsive buyers (Valkeneers and Vanhoomissen, 2012).

\subsection{Generation $Y$}

Generation Y, also known as Millennials, mainly refers to the cohort of people born between 1980 and 2000 (Erickson, 2008). Millennials have been exposed to the Internet from a very young age and that feature distinguishes them most from other generational cohorts (Bolton et al., 2013). Moreover, the Internet is an essential part of their everyday life (Issa and Isaias, 2016). As stressed by Bilgihan (2016), Generation Y is considered the least loyal generational cohort. For Millennials, choosing a product is the first step in their purchase process (Parment, 2013). Furthermore, the need for uniqueness strongly influences their retail-related behaviour (Rajamma et al., 2010).

Further, various social factors (e.g. products used by family and friends, products endorsed by celebrities, etc.) affect their online purchasing behaviour (Dhanapal et al., 2015). Regarding brand consciousness, Giovannini et al. (2015) identified public selfconsciousness and self-esteem to be of the utmost importance to Generation Y consumers. In that context, the impact of social media (Ruane and Wallace, 2013) and social media marketing (Bamini et al., 2014) are also underlined. As stressed by Noble et al. (2009), socialization and feelings of accomplishment also influence the consumption behaviour and preferences of members of the Generation Y. Consequently, they are more inclined to the extreme types of buying behaviour (Brougham et al., 2011).

\section{DEFINING FEATURES OF GENERATION Z}

Although there is no consensus about the precise boundaries of Generation Z, this generational cohort is made up of individuals born between the years 1995 and 2010 (White, 2017) and therefore can be aged ranging from 8 and 24 years old today in 2019. However, scientists have also indicated other time intervals associated with postmillennial generation, e.g., 1992-2008 (Talbott, 2013), 1994-2004 (Pollack et al., 2013), 1996-2010 (Fromm and Read, 2018), 1995-2004 (McDonald, 2011), 1995-2009 (Kuijer, 2011), and 1999-2010 (Patranabis, 2012).

A number of terms have been used to describe the first generation of the twentyfirst century such as: "I" Generation (Fyock et al., 2013), Pivotals (Fromm and Read, 2018), the Über Generation (Koulopoulos and Keldsen, 2014), Digital Natives (Patranabis, 2012), the "text generation" (Murgatroyd, 2011), the September 11 generation (Pollack et al., 2013), the net generation (Kuijer, 2011), generation me (Glass, 2007), the Google Generation (Gunter et al., 2009), hyper-connected generation (Haddouche and Salomone, 2018), and instant-gratification generation (Rota, 2017).

Apart from the years of birth, generation cohorts are influenced by different events that have taken place in their early childhood. Likewise, Rees Jones et al. (2008) outline that exposure to key historical events that have taken part during each cohort's transition to adulthood provides the markers for each generational field. In that sense, Pandit (2015) argues that the role of economy and, in particular, the role of the Great 
Recession of 2007 to 2009 has influenced the attitudes of Generation Z. Similarly, Herring and Thompson (2012) underline that the fall of the World Trade Centre and the crash of the financial markets have shaped their generational profile. Therefore, White (2017) stresses that the members of Generation $\mathrm{Z}$ develop their personalities and life skills in a socioeconomic environment characterized by chaos, uncertainty, volatility, and complexity. As a result, Generation Z cohort is focused on stable careers, security, safety, and privacy (Lanier, 2017).

Not surprisingly, Generation $\mathrm{Z}$ is often referred to as "the first true digital native generation" (Lanier, 2017). Moreover, using smartphones is the most important part of their life (Ozkan and Solmaz, 2015a). Consequently, Stillman and Stillman (2017) emphasize that Generation $\mathrm{Z}$ is "the first generation born into a world where every physical aspect (people and places) has a digital equivalent". In addition, they are snappy and live in the age of impatience (Van Den Bergh and Behrer, 2016). They are intuitively mobile (Pollack et al., 2013) and they prefer using information technology before faceto-face interaction (Herring and Thompson, 2012). Besides communication by text and voice, they communicate with each other by short video clips using mobile phones (Takahashi, 2011). Thus, Schawbel (2013) points to the fact that face-to-face communications are sometimes a challenge to the members of Generation Z.

Further, Generation Z students are open-minded, value honesty and embrace diversity (Seemiller and Grace, 2016). Although they share many habits, Generation Z is more responsible, smart, tolerant and inclusive than the millennial generation (Van Den Bergh and Behrer, 2016). Furthermore, they are ambitious and they do multitasking to the point of distraction (Hawley, 2014). Moreover, they perceive their self-organization in the future as a very dependent on the availability of smart technologies in both institutional settings and their personal lives (Roblek et al., 2019).

Despite turbulent environment, Chaston (2012) points out that Generation Z individuals are confident and optimistic, embracing traditional beliefs, valuing the family unit and self-control. Likewise, Ozkan and Solmaz (2015b) stress that they are selfconfident and want to secure their financial future. As far as Generation $\mathrm{Z}$ members are concerned, peer acceptance is very important (Chaston, 2012). One of the greatest influences on post-millennial generation is social media. However, Issa and Isaias (2016) raise the issue of Internet usage by Generation $\mathrm{Z}$ in the context of threats and obstacles to their cognitive, social and physical developments. Similarly, Knapp et al. (2017/2018) alert that Gen Z's tendency to be always plugged in makes them one of the unhealthiest generations both physically and emotionally.

\section{GENERATION Z IN THE PHYSICAL RETAIL ENVIRONMENT}

In contrast with other generational cohorts, little research has been conducted on Generation Z and their retail-related behaviour. According to Duffett (2017), Generation $\mathrm{Z}$ consumers are the lucrative and technologically advanced, but capricious. Furthermore, Schiffman et al. (2014) draw attention to the fact that Generation Z members can be characterized as spenders but not savers. Consequently, their consumer behaviour might 
lead to long-term debt and have negative implications for their long-term well-being and quality of their lives. Additionally, Gutfreund (2016/2017) argues that they are shrewd consumers who do not trust brands.

In March 2018, the National Retail Federation (NRF) and IBM's Institute for Business Value released a report entitled "What do Gen Z shoppers really want?" (https://nrf.com). The survey was conducted on 15,600 Generation Z members from 16 countries. Although they are digital native generation, the report revealed that they most often choose to shop in the physical store. More specifically, 98 percent of survey respondents globally said they typically make purchases in a store some or most of the time. The main findings of the report are summarized in Table 1.

Table 1. Generation Z shoppers

\begin{tabular}{|c|c|c|}
\hline \multirow{7}{*}{$\begin{array}{l}\text { Generation } \mathrm{Z} \\
\text { shoppers }\end{array}$} & Key elements & Main characteristics \\
\hline & $\begin{array}{l}\text { General } \\
\text { features }\end{array}$ & $\begin{array}{l}\text { - } \quad \text { Full of surprises } \\
\text { - Looking for reliability and consistence } \\
\text { whether they shop in a store, through an } \\
\text { app or on a website } \\
47 \text { percent of Generation } \mathrm{Z} \text { customers use } \\
\text { their smartphones when shopping in a } \\
\text { store }\end{array}$ \\
\hline & Store attributes & $\begin{array}{ll}\text { - } & \text { Wide product choice } \\
\text { - } & \text { Proximity of store location } \\
\text { - } & \text { Product availability } \\
\end{array}$ \\
\hline & Technology & $\begin{array}{l}\text { - Technology for easier, more rewarding } \\
\text { shopping } \\
\text { - Adding value and enhancing shopping } \\
\text { experience } \\
\text { - Little patience for technology that is } \\
\text { unresponsive or prone to errors }\end{array}$ \\
\hline & Brands & $\begin{array}{l}\text { - Actively collaborating and co-creating } \\
\text { with brands } \\
\text { - } \quad \text { Engaging with the brand on their terms } \\
\text { - Social media interaction with the brand }\end{array}$ \\
\hline & $\begin{array}{l}\text { Shopping } \\
\text { experience }\end{array}$ & $\begin{array}{l}\text { - } \quad \text { Desire for unique shopping experiences } \\
\text { - } \quad \text { Co-creating shopping experience }\end{array}$ \\
\hline & Expectations & $\begin{array}{l}\text { - Customization, robotics, augmented } \\
\text { reality (AR) and virtual reality (VR) }\end{array}$ \\
\hline
\end{tabular}

Source: Based on the report "What do Gen Z shoppers really want?", National Retail Federation (NFR) and IBM's Institute for Business Value (available at https://nrf.com)

Similarly, Skinner et al. (2018) notice that the emphasis should be put on desire for social interaction, involvement and co-creation of experiences. As for customer services, they like it personalized and efficient and they are expecting from companies to customize their shopping and buying experience, both online and offline (Gutfreund, 
2016/2017). Razum et al. (2017) analysed the sustainable consumption patterns of Generation $\mathrm{Z}$ in fashion industry and the factors influencing buying of fashion garments produced in line with the notion of sustainable development. The results revealed that the media, family and peers positively affect sustainable consumption of fashion.

It can be noted that the generation that grew up with information at their fingertips expects benefits from physical retail stores (Figure 1). Pantano and Naccarato (2010) highlight the importance of an enjoyable experience during the shopping activity. As Generation $\mathrm{Z}$ consumers are concerned, their in-store shopping experiences should consist of socialization, novelty, entertainment, instant gratification, interaction and enjoyment. Consequently, the synergistic effects of these factors affect creation of Generation Z's unique in-store shopping experiences. On the other hand, by linking the in-store customer experience with a digital one, retailers gain access to more consumer data.

Figure 1. Expectations of Generation $\mathrm{Z}$ in physical retail stores

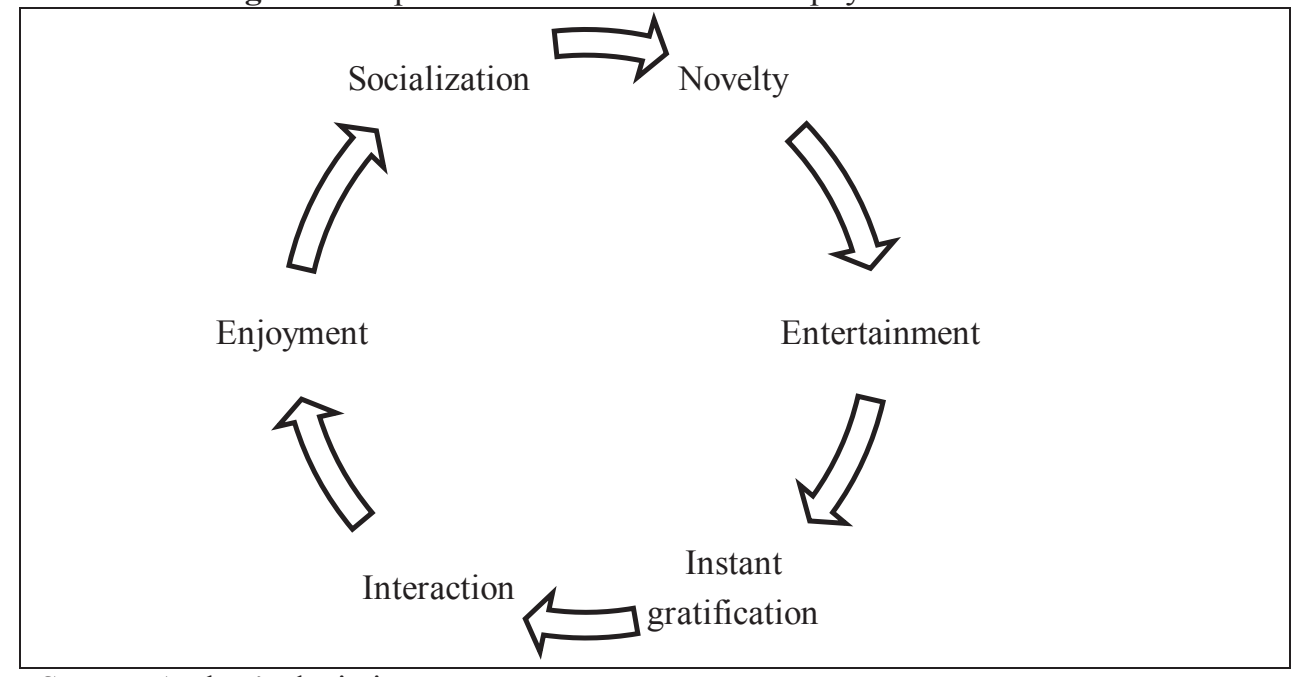

Source: Author's depiction

Priporas et al. (2017) explored Generation Z consumers' current perceptions, expectations and recommendations in terms of their future interactions in smart retailing context. The findings revealed that smart technologies have a significant influence on Generation Z consumers' experiences. In addition, the study showed that Generation Z consumers expect of the technology to enable them more informed shopping decisions.

With the rapid advances in Internet technology, many retailers view Internet of Things as a potential basis for achieving sustainable competitive advantage and long-term profitability (Balaji et al., 2017). According to the aforementioned report (https://nrf.com), Generation Z consumers are eager to adopt innovative solutions that provide direct value and enhance the shopping experience. As regards future shopping 
technologies, Generation $\mathrm{Z}$ consumers indicated tools that allow them to try out products in-store (e.g. "magic mirror"), customize products for themselves, design unique products and create on-site with a $3 \mathrm{D}$ printer, robotic technologies as well as interactive screens and other tools that help them go online while they are in a store.

\section{WHERE NEXT FOR GENERATION Z: RESEARCH PROPOSITIONS}

In the present digital era, brick-and-mortar retailing is being challenged to become smarter and provide greater value to both consumers and retailers (Dacko, 2017). As regards post-millennial generation, great importance should be put on the introduction of innovative smart technologies in the physical retail environment. Consequently, future work should concentrate on the effects of smart technology on Generation Z customers' experience. Furthermore, in a brick-and-mortar retail context it is of utmost importance to identify how smart technologies affect the traditional customer decision-making process.

It can be argued that many customer-facing Internet of Things technologies have become an integral part of the retail industry. These include smart shopping carts, augmented reality, interactive displays, smart mirror interactive technology (magic mirrors or memory mirrors), RFID tags, and smart kiosks (Balaji et al., 2017). In the context of smart applications in the retail industry, Chaudhuri (2018) describes smart dressing/fitting rooms, smart shelves, smart advertising using beacons, intelligent vending machines and store screening robots. In addition, Renko and Druzijanic (2014) highlight that innovative technologies help consumers to make their shopping decisions. Therefore, Kumar Roy et al. (2018) stress that retail stores should focus on smart technologies that are simple, yet offer enhanced customer value through improved shopping efficiency.

Further research is also needed to determine Generation Z customers' awareness, attitude, and preferences towards different smart technologies in the retail sector. In addition, their acceptance of and resistance to these technologies are also questions in need of further investigation. Kumar Roy et al. (2017) assert that smart customer experience directly enhances satisfaction and reduces perceived risk. Consequently, further studies should also look into the impact of innovative smart technologies on Generation Z customers' satisfaction and willingness to buy.

Store atmospherics are widely considered an important factor when influencing customer behaviour. Moreover, retail marketing literature abounds with analyses of the importance of store atmospherics for determining the overall shopping experience. However, when it comes to Generation Z, not much is known about the impact of store atmospherics on behavioural intention and in-store customer shopping experience. Therefore, further research should deal with the influence of retail store environmental cues on Generation Z consumers' behaviour. In addition, their emotional responses to store atmospheric cues as well as the effects of store satisfaction and store atmosphere on loyalty are also challenging issues to examine. 
Unfortunately, until today little research has addressed the Generation $\mathrm{Z}$ consumers' preferences for manufacturer vs. store brands. More work should be done in the following areas: Generation Z consumers' attitude towards store brands, the impact of store brands on consumer store loyalty, store brands' purchase intention, consumer choice of store brands across various store formats, and effects of store brand price-image and service quality on store brand purchase intention. In addition, the creation of Generation $\mathrm{Z}$ consumers' loyalty and trust in the retailer through store brands should be analysed.

Brand loyalty is another popular research area in need of further examination. Unfortunately, the issue of brand loyalty behaviour of Generation $\mathrm{Z}$ consumers is still poorly understood. In this sense, Gutfreund (2016/2017) points out that earning Generation Z consumers' loyalty will be a challenge, and brands will need to rethink their marketing strategies. In particular, the various patterns of brand loyalty used by Generation Z should be determined. Additionally, future studies should deal with the effects of satisfaction, trust, and brand image on brand loyalty. It would be interesting to compare the loyalty profile of various socio-demographic categories of post-millennial consumers in order to determine their behaviour. In addition, the most important elements of brand evaluation used by Generation $\mathrm{Z}$ consumers should be identified.

\section{CONCLUSION}

The latest technological developments, in particular smart innovative technologies create a number of opportunities for brick-and-mortar retailers to understand consumer preferences regarding store experience and to meet their expectations. On the other hand, these technological advancements help retailers to gather various customerrelated information and to identify their shopping preferences and purchasing trends. Therefore, advanced technologies provide retailers with greater insights on their customer base to gain a better understanding of their habits and needs. However, brick-and-mortar retailers need to introduce customers to the smart technologies they utilize to co-create a more personalized, unique experience.

Based on a comprehensive review of the academic and practitioner literature, the paper synthesise current findings to contribute to the existing body of knowledge on the topic of little researched, yet important Generation $\mathrm{Z}$ cohort. In addition, it may present a starting point for better understanding and researching the phenomenon of advanced technology usage in brick-and-mortar retail settings.

The paper also provides useful insights for brick-and-mortar retailers that are approaching the Generation $\mathrm{Z}$ consumers. Through a better understanding of their behaviour, both brick-and-mortar retailers and marketers will be able to develop strategies to improve their services and better satisfy the needs and requirements of this unique generation of consumers. In particular, investing in smart innovative technologies provides new experiences for consumers and creates differentiation in brick-and-mortar retail settings. Furthermore, it enables individualization and personalization of 
Generation Z consumers' shopping experiences. Consequently, Generation Z consumers will be better targeted and the overall retail experience will be enhanced.

Taking into account future research propositions, this paper may give a background to further empirical research on the post-millennial generation. Bearing in mind that no empirical analysis has been included in the paper, it lacks a contribution to this field from an empirical point of view. To this end, additional research is needed to provide empirical support to deepen understanding of Generation $Z$ and its role in the brick-and-mortar retail environment. On a wider level, future research needs to be carried out to identify how the introduction of advanced technologies modifies the brick-andmortar retailing context. In particular, an important issue to examine is how smart innovative technologies affect Generation $\mathrm{Z}$ cohort in a retail environment and their overall shopping experience.

\section{REFERENCES:}

1. Balaji, M. S., Kumar Roy, S., Sengupta, A. and Chong, A. (2017). User Acceptance of IoT Applications in Retail Industry. In: I. Lee, ed., The Internet of Things in the Modern Business Environment. Hershey: IGI Global, pp. 28-49. https://doi.org/10.4018/978-1-5225-2104-4.ch002

2. Bamini, K. P. D., Balakrishnan, M. I. D. and Yi, W. J. (2014). The Impact of Social Media Marketing Medium toward Purchase Intention and Brand Loyalty among Generation Y. Procedia - Social and Behavioral Sciences, 148, pp. 177185. https://doi.org/10.1016/j.sbspro.2014.07.032

3. Benckendorff, P., Moscardo, G. and Pendergast, D. (2010). Tourism and Generation Y. Oxfordshire: Cabi.

4. Benckendorff, P. and Moscardo, G. (2013). Generational cohorts and ecotourism. In: R. Ballantyne and J. Packer, eds., International Handbook on Ecotourism. Cheltenham: Edward Elgar Publishing Limited, pp. 135-154. https://doi.org/10.4337/9780857939975.00018

5. Bilgihan, A. (2016). Gen Y customer loyalty in online shopping: An integrated model of trust, user experience and branding. Computers in Human Behavior, 61, pp. 103-113. https://doi.org/10.1016/j.chb.2016.03.014

6. Bolton, R. N., Parasuraman, A., Hoefnagels, A., Migchels, N., Kabadayi, S., Gruber, T., Komarova Loureiro, Y. and Solnet, D. (2013). Understanding Generation Y and their use of social media: a review and research agenda. Journal of Service Management, 24(3), pp. 245-267. https://doi.org/10.1108/09564231311326987

7. Brosdahl, D. J. C. and Carpenter, J. M. (2012). U.S. male generational cohorts: Retail format preferences, desired retail attributes, satisfaction and loyalty. Journal of Retailing and Consumer Services, 19(6), pp. 545-552. https://doi.org/10.1016/j.jretconser.2012.06.005

8. Brougham, R. R., Jacobs-Lawson, J. M., Hershey, D. A. and Trujillo, K. M. (2011). Who pays your debt? An important question for understanding 
compulsive buying among American college students. International Journal of Consumer Studies, 35(1), pp. 79-85. https://doi.org/10.1111/j.14706431.2010.00923.x

9. Chaston, I. (2012). Public Sector Reformation: Values-driven Solutions to Fiscal Constraint. London: Palgrave Macmillan. https://doi.org/10.1057/9780230379350

10. Chaudhuri, A. (2018). Internet of Things, for Things, and by Things. Boca Raton: CRC Press. https://doi.org/10.1201/9781315200644

11. Cohler, B. J. and Hostetler, A. (2003). Linking Life Course and Life Story. In: J. T. Mortimer and M. J. Shanahan, eds., Handbook of the Life Course. New York: Springer, pp. 555-576. https://doi.org/10.1007/978-0-306-48247-2_25

12. Dacko, S. G. (2017). Enabling smart retail settings via mobile augmented reality shopping apps. Technological Forecasting and Social Change, 124, pp. 243256. https://doi.org/10.1016/j.techfore.2016.09.032

13. Dhanapal, S., Vashu, D. and Subramaniam, T. (2015). Perceptions on the challenges of online purchasing: a study from "baby boomers", generation " $\mathrm{X}$ " and generation "Y" point of views. Contaduría y Administración, 60(S1), pp. 107-132. https://doi.org/10.1016/j.cya.2015.08.003

14. Duffett, R. G. (2017). Influence of social media marketing communications on young consumers' attitudes. Young Consumers, 18(1), pp. 19-39. https://doi.org/10.1108/YC-07-2016-00622

15. Erickson, T. J. (2008). Plugged In: The Generation Y Guide to Thriving at Work. Boston, Massachusetts: Harvard Business Press.

16. Fromm, J. and Read, A. (2018). Marketing to Gen Z: The Rules for Reaching This Vast and Very Different Generation of Influencers. New York: Amacom.

17. Fyock, C., Finney, M. I., Robbins, S. P. and Thompson, L. (2013). The Truth About Managing Effectively (Collection). New Jersey: Pearson Education.

18. Gibson, J. W., Regina, G. and Edwards, M. (2009). Generational Differences in a Workplace: Personal Values, Behaviours and Popular Beliefs. Journal of Diversity Management, 4(3), pp. 1-8.

19. Giovannini, S., Xu, Y. and Thomas, J. (2015). Luxury fashion consumption and Generation Y consumers: Self, brand consciousness, and consumption motivations. Journal of Fashion Marketing and Management, 19(1), pp. 22-40. https://doi.org/10.1108/JFMM-08-2013-0096

20. Glass, A. (2007). Understanding generational differences for competitive success. Industrial and Commercial Training, 39(2), pp. 98-103. https://doi.org/10.1108/00197850710732424

21. Gunter, B., Rowlands, I. and Nicholas, D. (2009). The Google Generation: Are ICT innovations Changing information Seeking Behaviour? Oxford: Chandos Publishing. https://doi.org/10.1533/9781780631639

22. Gutfreund, J. (2016/2017). Move over, Millennials: Generation $Z$ is changing the consumer landscape. Journal of Brand Strategy, 5(3), pp. 245-249. 
23. Haddouche, H. and Salomone, C. (2018). Generation $Z$ and the tourist experience: tourist stories and use of social networks. Journal of Tourism Futures, 4(1), pp. 69-79. https://doi.org/10.1108/JTF-12-2017-0059

24. Hawley, C. (2014). People Skills. New York: Penguin Group.

25. Herring, J. and Thompson, L. (2012). Learn the Art of Logic and Persuasion (Collection). New Jersey: FT Press.

26. Issa, T. and Isaias, P. (2016). Internet factors influencing generations $\mathrm{Y}$ and $\mathrm{Z}$ in Australia and Portugal: A practical study. Information Processing \& Management, 52(4), pp. 592-617. https://doi.org/10.1016/j.ipm.2015.12.006

27. Knapp, C. A., Weber, C. and Moellenkamp, S. (2017/2018). Challenges and strategies for incorporating Generation $\mathrm{Z}$ into the workplace. Corporate Real Estate Journal, 7(2), pp. 137-148.

28. Koulopoulos, T. and Keldsen, D. (2014). Gen Z Effect: The Six Forces Shaping the Future of Business. New York: Bibliomotion.

29. Kuijer, A. (2011). Think Small, Grow Big: A Social Media Survival Guide for the Marketing Professional. New York: Cosimo Books.

30. Kumar Roy, S., Balaji, M. S., Sadeque, S., Nguyen, B. and Melewar, T. C. (2017). Constituents and consequences of smart customer experience in retailing. Technological Forecasting and Social Change, 124, pp. 257-270. https://doi.org/10.1016/j.techfore.2016.09.022

31. Kumar Roy, S., Balaji, M. S., Quazi, A. and Quaddus, M. (2018). Predictors of customer acceptance of and resistance to smart technologies in the retail sector. Journal of Retailing and Consumer Services, 42, pp. 147-160. https://doi.org/10.1016/j.jretconser.2018.02.005

32. Lanier, K. (2017). 5 things HR professionals need to know about Generation Z: Thought leaders share their views on the HR profession and its direction for the future. Strategic HR Review, 16(6), pp. 288-290. https://doi.org/10.1108/SHR08-2017-0051

33. Lantos, G. P. (2011). Consumer Behavior in Action: Real-life Applications for Marketing Managers. New York: M. E. Shape.

34. Leung, J. W. K. and Taylor, G. (2002). Fashion buying criteria of X Generation consumers in Hong Kong. Journal of Fashion Marketing and Management: An International Journal, 6(1), pp. 63-76. https://doi.org/10.1108/13612020210422473

35. McCrindle, M. (2014). The ABC of XYZ: Understanding the Global Generations. Bella Vista: McCrindle Research Pty Ltd.

36. McDonald, K. (2011). How to Market to People Not Like You: "Know It or Blow It" Rules for Reaching Diverse Customers. New Jersey: John Wiley \& Sons.

37. Meneely, L., Strugnell, C. and Burns, A. (2009). Elderly consumers and their food store experiences. Journal of Retailing and Consumer Services, 16(6), pp. 458-465. https://doi.org/10.1016/j.jretconser.2009.06.006

38. Miller, J. D. and Laspra, B. (2017). Generation X in Mid-Life: A Summary from the Longitudinal Study of American Life. Generations, 41(3), pp. 27-33. 
39. Moschis, G. P., Lee, E., Mathur, A. and Strautman, J. 2000. The Maturing Marketplace: Buying Habits of Baby Boomers and Their Parents. Westport: Quorum Books.

40. Moschis, G., Curasi, C. and Bellenger, D. (2004). Patronage motives of mature consumers in the selection of food and grocery stores. Journal of Consumer Marketing, 21(2), pp. 123-133. https://doi.org/10.1108/07363760410525687

41. Murgatroyd, S. (2011). Rethinking Education: Learning and the New Renaissance. Edmonton: Future Think Press.

42. Myers, H. and Lumbers, M. (2008). Understanding older shoppers: a phenomenological investigation. Journal of Consumer Marketing, 25(5), pp. 294-301. https://doi.org/10.1108/07363760810890525

43. Noble S. M, Haytko, D. L. and Phillips, J. (2009). What drives college-age Generation Y consumers?, Journal of Business Research, 62(6), pp. 617-628. https://doi.org/10.1016/j.jbusres.2008.01.020

44. Ordun, G. (2015). Millennial (Gen Y) Consumer Behavior, Their Shopping Preferences and Perceptual Maps Associated With Brand Loyalty. Canadian Social Science, 11(4), pp. 40-55.

45. Ozkan, M. and Solmaz, B. (2015a). Mobile Addiction of Generation Z and its Effects on their Social Lives: (An Application among University Students in the 18-23 Age Group). Procedia - Social and Behavioral Sciences, 205, pp. 92-98. https://doi.org/10.1016/j.sbspro.2015.09.027

46. Ozkan, M. and Solmaz, B. (2015b). The Changing Face of the Employees Generation Z and Their Perceptions of Work (A Study Applied to University Students). Procedia - Social and Behavioral Sciences, 26, pp. 476-483.

47. Pak, C. and Kambil, A. (2006). Over 50 and ready to shop: serving the aging consumer. Journal of Business Strategy, 27(6), pp. 18-28. https://doi.org/10.1108/02756660610710319

48. Pandit, V. (2015). We Are Generation Z: How Identity, Attitudes, and Perspectives Are Shaping Our Future. Dallas, Texas: Brown Books Publishing Group.

49. Pantano, E. and Naccarato, G. (2010). Entertainment in retailing: The influences of advanced technologies. Journal of Retailing and Consumer Services, 17(3), pp. 200-204. https://doi.org/10.1016/j.jretconser.2010.03.010

50. Parment, A. (2012). Generation Y in Consumer and Labour Markets. New York: Routledge.

51. Parment, A. (2013). Generation Y vs. Baby Boomers: Shopping behavior, buyer involvement and implications for retailing. Journal of Retailing and Consumer Services, 20(2), pp. 189-199. https://doi.org/10.1016/j.jretconser.2012.12.001

52. Patranabis, I. C. (2012). The Future of Workforce Management: Perspectives and Way Ahead. In: R. K. Mishra, S. Sarkar and P. Singh., eds., Today's HR for a Sustainable Tomorrow. New Delhi: Allied Publishers, pp. 92-99.

53. Pettigrew, S. (2007). Reducing the Experience of Loneliness among Older Consumers. Journal of Research for Consumers, 12, pp. 1-14. 
54. Pollack, S., Pollack, N. and Havenner, M. (2013). Disrupted, From Gen Y to iGen: Communicating With The Next Generation. Los Angeles: Pacific Coast Creative Publishing.

55. Priporas, C.-V., Stylos, N. and Fotiadis, A.K. (2017). Generation Z consumers' expectations of interactions in smart retailing: A future agenda. Computers in Human Behavior, 77, pp. 374-381. https://doi.org/10.1016/j.chb.2017.01.058

56. Rajamma, R. K., Pelton, L. E., Hsu, M. K. and Knight, D. K. (2010). The Impact of Consumers' Need for Uniqueness and Nationality on Generation Y's Retail Patronage Behaviors: Investigating American and Taiwanese Consumers. Journal of Global Marketing, 23(5), pp. 387-410. https://doi.org/10.1080/08911762.2010.521112

57. Razum, A., Pandža Bajs, I. and Zekić, Z. (2017). The analysis of the sustainable consumption patterns of generation $\mathrm{Z}$ in fashion industry. Ekonomski pregled, 68(3), pp. 297-318.

58. Rees Jones, I., Hyde, M., Victor, C. R., Wiggins, R. D., Gilleard, C. and Higgs, P. (2008). Ageing in a Consumer Society: From Passive to Active Consumption in Britain. Bristol: The Policy Press. https://doi.org/10.2307/j.ctt9qgmgm

59. Renko, S. and Druzijanic, M. (2014). Perceived usefulness of innovative technology in retailing: Consumers' and retailers' point of view. Journal of Retailing and Consumer Services, 21(5), pp. 836-843. https://doi.org/10.1016/j.jretconser.2014.02.015

60. Research Report: What do Gen Z shoppers really want?, available at: https://nrf.com/system/tdf/Documents/retail\%20library/NRFIBM $\% 20$ Generation $\% 20 Z \% 20$ Study $\% 20$ Part $\% 20$ III.pdf?file $=1 \&$ title $=$ What $\%$ $20 \mathrm{do} \% 20 \mathrm{Gen} \% 20 \mathrm{Z} \% 20$ shoppers\%20really\%20want? (Accessed 1 October 2018)

61. Roblek, V., Mesko, M., Dimovski, V. and Peterlin, J. (2019). Smart technologies as social innovation and complex social issues of the $\mathrm{Z}$ generation. Kybernetes, 48(1), pp. 91-107. https://doi.org/10.1108/K-09-2017-0356

62. Rota, S. (2017). The Gen Z Answer Key for Business: The Go-To Guide for Marketing to Generation Z. Aurora, Colorado: WaveCloud Corporation.

63. Ruane, L. and Wallace, E. (2013). Generation Y females online: insights from brand narratives. Qualitative Market Research: An International Journal, 16(3), pp.: 315-335. https://doi.org/10.1108/13522751311326125

64. Sagrestano, R. and Wahlers, E. (2012). The Philanthropic Planning Companion: The Fundraisers' and Professional Advisors' Guide to Charitable Gift Planning. Hoboken, New Jersey: John Wiley \& Sons, Inc.

65. Schawbel, D. (2013). Promote Yourself: The New Rules for Career Success. New York: St. Martin's Press.

66. Schewe, C. D. and Meredith, G. (2004). Segmenting global markets by generational cohorts: determining motivations by age. Journal of Consumer Behaviour. 4(1), pp. 51-63. https://doi.org/10.1002/cb.157

67. Schiffman, L., O’Cass, A., Paladino, A. and Carlson, J. (2014). Consumer Behaviour. French's Forest NSW: Pearson Australia. 
68. Seemiller, C. and Grace, M. (2016). Generation Z Goes to College. San Francisco: Jossey-Bass.

69. Skinner, H., Sarpong, D. and White, G. R. T. (2018). Meeting the needs of the Millennials and Generation $\mathrm{Z}$ : gamification in tourism through geocaching. Journal of Tourism Futures, 4(1), pp. 93-104. https://doi.org/10.1108/JTF-122017-0060

70. Stillman, D. and Stillman, J. (2017). Gen Z Work: How the Next Generation Is Transforming the Workplace. New York: Harper Business.

71. Sudbury-Riley, L. (2014). Unwrapping senior consumers' packaging experiences. Marketing Intelligence \& Planning, 32(6), pp. 666-686. https://doi.org/10.1108/MIP-02-2013-0027

72. Takahashi, T. (2011). Japanese Youth and Mobile Media. In: M. Thomas, ed., Deconstructing Digital Natives: Young People, Technology and the New Literacies. New York: Routledge. pp. 67-82.

73. Talbott, C. (2013). Essential Career Transition Coaching Skills. New York: Routledge. https://doi.org/10.4324/9780203362129

74. Valkeneers, G. and Vanhoomissen, T. (2012). Generations living their own life: The differences in lifestyle and consumer behaviour between busters and baby boomers. Journal of Customer Behaviour, 11(1), pp. 53-68. https://doi.org/10.1362/147539212X13286273975274

75. Van Den Bergh, J. and Behrer, M. (2016). How Cool Brands Stay Hot: Branding to Generations $Y$ and $Z$. London: Kogan Page Limited.

76. White, J. E. (2017). Meet Generation Z: Understanding and Reaching the New Post-Christian World. Grand Rapids: Baker Books.

77. Worsley, T., Wang, W. C. and Hunter, W. (2011). Baby boomers' reasons for choosing specific food shops. International Journal of Retail \& Distribution Management, 39(11), pp. 867-882. https://doi.org/10.1108/09590551111177972

78. Wyn, J. (2012). The making of a generation: policy and the lives and aspirations of Generation X. Journal of Educational Administration and History, 44(3), pp. 269-282. https://doi.org/10.1080/00220620.2012.683392

79. Yin, Y., Pei, E. and Ranchhod, A. (2013). The shopping experience of older supermarket consumers. Journal of Enterprise Information Management, 26(4), pp. 444-471. https://doi.org/10.1108/JEIM-05-2013-0025 


\title{
GENERACIJA Z U TRADICIONALNIM PRODAVAONICAMA: PREGLED I PRIJEDLOZI ISTRAŽIVANJA
}

\author{
Izv. prof. dr. sc. Katija Vojvodic ${ }^{24}$
}

\begin{abstract}
Sažetak
Za razliku od ranijih generacijskih skupina Baby Boomers, generacije $X i$ generacije $Y$, generacija $Z$ (poznata $i$ kao post-milenijska generacija) još je uvijek nedovoljno istražena tema u kontekstu njezina maloprodajnog ponašanja. Iako postoje znatne razlike među generacijama, može se tvrditi da svaka generacijska skupina utječe na način poslovanja tradicionalnih maloprodavača. Uz to, tradicionalni se maloprodavači suočavaju s rastućom konkurencijom, posebice od strane internetskih maloprodavača. Osim toga, kupovne navike značajno mijenjaju maloprodajni sektor pa tradicionalni maloprodavači moraju prilagoditi svoje strategije kako bi zadovoljili zahtjeve suvremenih potrošača koji se brzo mijenjaju. Na temelju dosadašnje literature, svrha je rada identificirati glavna obilježja post-milenijske generacije u kontekstu tradicionalne maloprodaje. Nadalje, u radu se razvija okvir koji može dati smjernice za buduća istraživanja i pomoći tradicionalnim maloprodavačima kako bi se bolje usmjerili na post-milenijsku generaciju. Ključno je za tradicionalne maloprodavače pravilno pristupiti generaciji Z kako bi učinkovitije osvojili taj tržišni segment te kako bi poboljšali njihovo cjelokupno kupovno iskustvo.
\end{abstract}

Ključne riječi: tradicionalni maloprodavači, generacija Z, ponašanje potrošača JEL klasifikacija: J1, L81

${ }^{24}$ Izv. prof. dr. sc. Katija Vojvodić, Sveučilište u Dubrovniku, Odjel za ekonomiju i poslovnu ekonomiju, E-mail: katija.vojvodic@unidu.hr 